\title{
Effects of vasopressin on open-field behavior in rats
}

\author{
A. F. CRINE \\ Laboratory of Experimental Psychology, University of Liège, B-4020 Liège Belgium
}

\begin{abstract}
The aim of this experiment was to assess the effects of subcutaneous injections of lysinevasopressin on the locomotor behavior of rats in an open-field situation. The results obtained showed greater peripheral locomotor activity in the placebo group during the first session, greater central area locomotor activity and a more evident gradual locomotor immobility with significant differences during the second and the fifth sessions in the experimental group. These results are discussed in terms of emotionality level, habituation, and physical and procedural characteristics of the experiment.
\end{abstract}

It is now recognized that vasopressin, a pituitary peptide, has many behavioral actions, particularly at the level of mnemic functions (Bohus, 1971; de Wied \& Bohus, 1979; van Ree, Bohus, Versteeg, \& de Wied, 1978; van Wimersma Greidanus, Bohus, \& de Wied, 1975). The role of vasopressin has been assessed in studies dealing with partially and with fully hypophsectomized rats; these animals could not maintain an acquired avoidance behavior (de Wied, 1964, 1965). The administration of exogenous vasopressin restored this behavior (Bohus, Gispen, \& de Wied, 1973; Lande, Witter, \& de Wied, 1971). Moreover, in intact rats, vasopressin increased the resistance to extinction of both passive and active avoidance behavior (Ader $\&$ de Wied, 1972; Bohus, Ader, \& de Wied, 1972; de Wied, 1971). The behavioral role of vasopressin has also been demonstrated in rats with diabetes insipidus, which lack the ability to synthesize vasopressin (Bohus, van Wimersma Greidanus, \& de Wied, 1975; de Wied, Bohus, \& van Wimersma Greidanus, 1975; Valtin \& Schroeder, 1964). These studies suggest that vasopressin is involved in long-term memory processes. Evidence for such an effect can also be derived from experiments in which vasopressin exhibits antiamnesic effects (Bookin \& Pfeifer, 1977; Flexner, Flexner, Hoffman, \& Walter, 1977; Rigter, van Riezen, $\&$ de Wied, 1974). The aim of this study was to analyze the effects of vasopressin on the locomotor activity of rats in an open-field situation, since the possible modifications of locomotor activity might reflect the emotivity-level variations that vasopressin would induce.

\section{METHOD}

\section{Subjects}

Forty male Sprague-Dawley rats (Animalabo, Brussels) were used.

Requests for reprints should be sent to the author, Laboratoire de Psychologie expérimentale, Université de Liège, boulevard de la Constitution 32, B-4020, Liège, Belgium.
Their weights at the beginning of the experiment were 300-350 g. They lived in individual home cages with free access to water and food. The light was on from 8:30 a.m. to 5:30 p.m. The 20 rats in the experimental group were injected subcutaneously with lysinevasopressin (Sandoz), at a dose of $1 \mathrm{IU} / \mathrm{kg}$ in $5 \mathrm{ml}$ saline, $1 \mathrm{~h}$ prior to each daily session. The 20 rats in the placebo group were injected subcutaneously with $\mathrm{NaCl} 9 \%, 5 \mathrm{ml} / \mathrm{kg}$, under the same conditions.

\section{Apparatus}

The open field was a wooden square box $(70 \times 70 \mathrm{~cm})$ with $24-\mathrm{cm}$-high walls. White lines divided the black floor into 25 equal squares $(14 \times 14 \mathrm{~cm})$. Illumination was provided by a $100-\mathrm{W}$ bulb placed $150 \mathrm{~cm}$ above the center of the field. In an attempt to create a familiar environment that would limit unnecessary emotional response to the testing apparatus, the floor was partially covered with the subjects' own soiled litter.

\section{Procedure}

At the beginning of the session, one rat was placed in a curner of the apparatus. The same corner was used for all rats. Locomotor activity was observed and recorded during five 5-min sessions. Each observation session was divided into five 1-min periods. An "event" was recorded whenever an animal placed both forelegs on a new square. Separate records were kept for entering peripheral and central squares. The testing was repeated at the same time for 5 consecutive days. Significant differences were calculated using Mann-Whitney U, Wilcoxon two-tailed nonparametric, and two-way proportions tests. The $5 \%$ level of significance was employed in all tests.

\section{RESULTS}

The various possible locomotor behaviors were considered separately. They were assigned to three categories:

(1) Locomotion along the walls (16 peripheral squares). The experimental group showed a gradual decrease of locomotor activity scores. There was a significant decrease between the first session and the last two sessions (Wilcoxon $\mathrm{T}=42, \mathrm{p}<.02 ; \mathrm{T}=33$, $\mathrm{p}<.01)$, between the second and third sessions $(\mathrm{T}=$ $23.5, \mathrm{p}<.02)$, and between the second and fifth sessions $(T=27.5, p<.02)$. The placebo group also showed a gradual decrease in locomotor activity 
scores. There was a significant decrease between the first session and each of the other sessions (Wilcoxon Ts $=11,6,6,0 ; p<.01)$, between the second session and the third $(T=33, p<.02)$, between the second session and the fifth $(T=19.5, \mathrm{p}<.01)$, and between the fourth session and the fifth $(T=28, p<.02)$. Between-groups comparisons showed significantly greater locomotor activity in the placebo group during the first session (Mann-Whitney $U=56.5, \mathrm{p}<.002$ ) but no difference during further sessions $(p>.05)$. Locomotor activity scores in both experimental and placebo groups are shown in Figure 1. These scores are the average numbers of peripheral squares entered in each group.

(2) Locomotion in the center of the field. In the experimental group, the inner squares were visited more frequently during the first session (proportions test: $\operatorname{Pr} 1=.55, \operatorname{Pr} 2=.35, \operatorname{Pr} 3=.2, \operatorname{Pr} 4=.1, \operatorname{Pr} 5=.15$; $\mathrm{p}<.05)$. Then a gradual diminution was followed by a stabilization. In the placebo group, a decrease in the number of central squares entered was also recorded, but the development was different; there was a total drop during the second session followed by stabilization at a level higher than that of the experimental group. The number of central squares visited during the first session was significantly greater (proportions test: $\operatorname{Pr} 1=.35, \operatorname{Pr} 2=0, \operatorname{Pr} 3=.1, \operatorname{Pr} 4=$ $.15, \operatorname{Pr} 5=.1 ; p<.05)$. The activity scores for both groups are shown in Figure 2. The scores are expressed by the number of rats in each group displaying the behavior under study.

When the observations of the five sessions were pooled, it appeared that rats injected daily with vasopressin visited the central field more often (MannWhitney $U=123.5, p<.05)$. This is illustrated by Figure 3. The criterion used was that a rat enter the central area at least once.

(3) No locomotor activity. The criterion used for

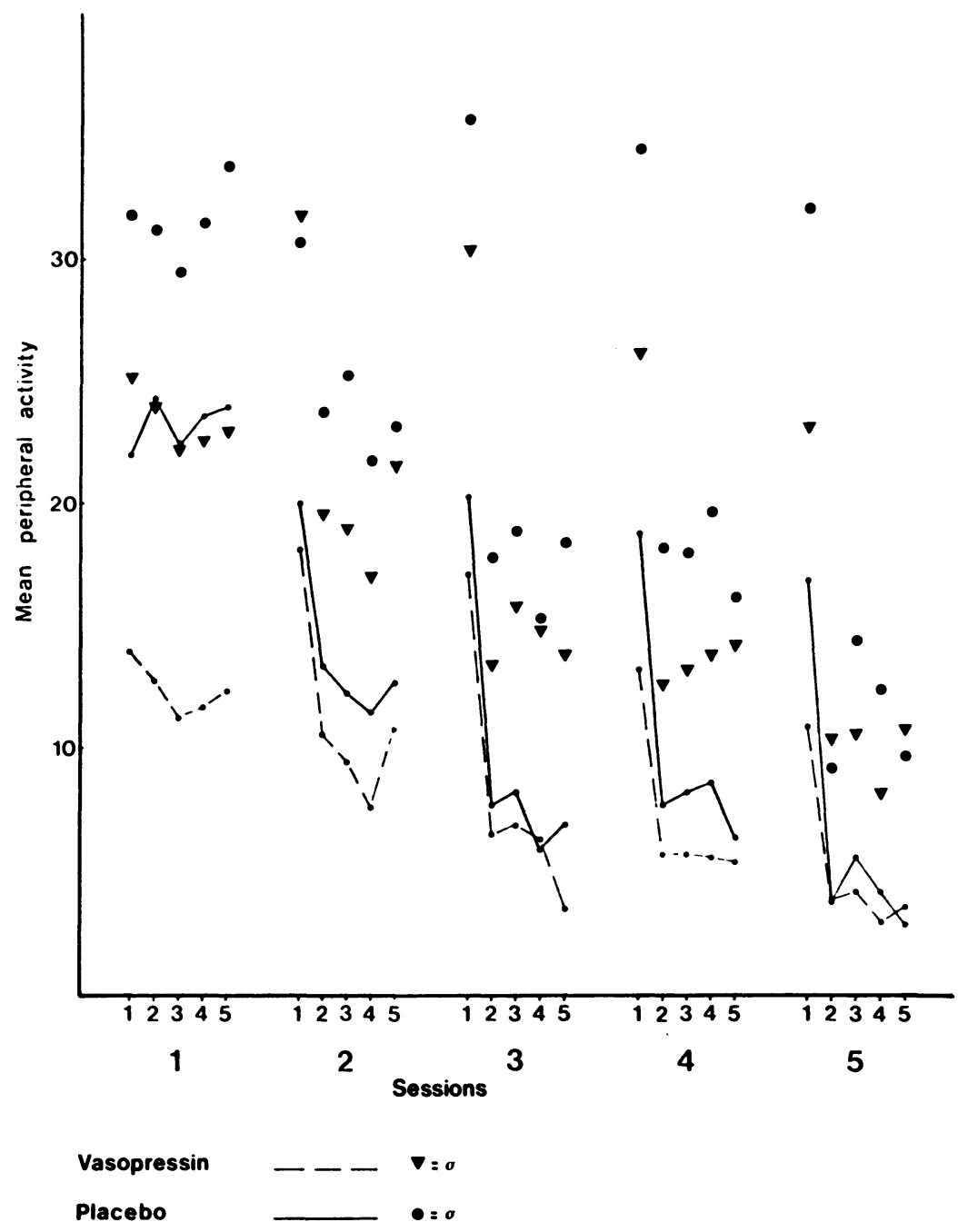

Figure 1. Mean number of peripheral squares entered in each of the five 1-min periods of the five daily sessions for each group. 


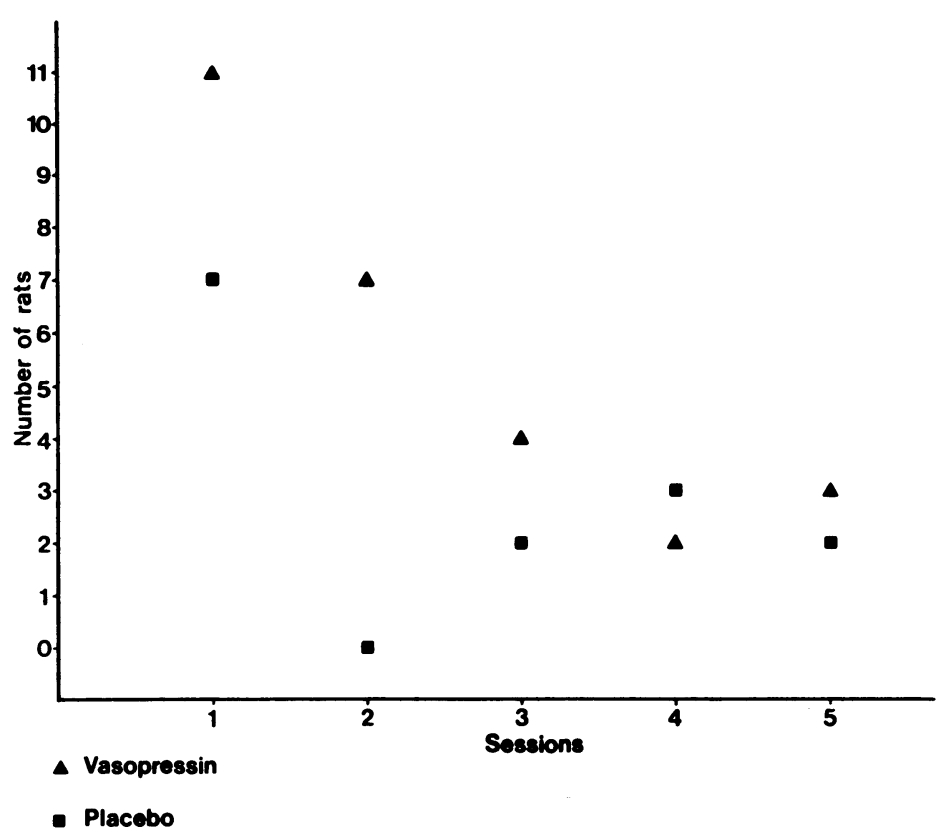

Figure 2. Evolution of the number of rats entering the central field in each group.

scoring was that an animal not leave the starting square or show locomotor activity during the entire session. Both groups showed a gradual increase in the number of rats with no-activity scores (experimental group: $\operatorname{Pr} 1=0, \operatorname{Pr} 2=.2, \operatorname{Pr} 3=.2, \operatorname{Pr} 4=.2, \operatorname{Pr} 5=.4$ placebo group: $\operatorname{Pr} 1=0, \operatorname{Pr} 2=0, \operatorname{Pr} 3=.1, \operatorname{Pr} 4=.1$, $\operatorname{Pr} 5=.15)$. However, the development of the groups

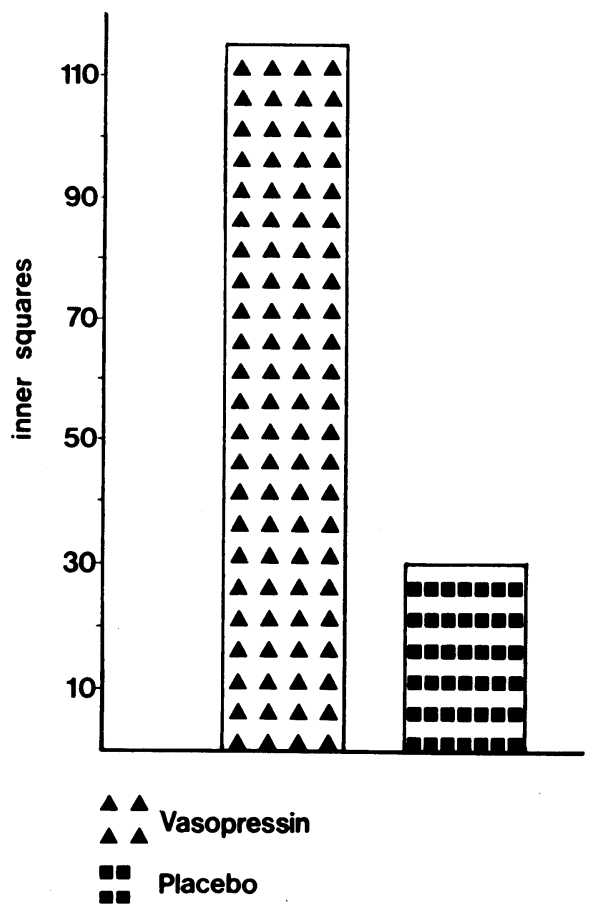

Figure 3. Total number of central squares entered in all openfield sessions. was different. There was a more gradual increase in the number of subjects displaying this behavior in the experimental group. Furthermore, during the second and fifth sessions, there were significantly more subjects with no locomotor activity in the experimental group than in the placebo group (proportions test: $\mathrm{p}<.05$ ). Figure 4 shows the development of both groups' nonlocomotor behavior.

\section{DISCUSSION}

Since its introduction 40 years ago (Hall, 1934), the open-field test has been employed mainly as a simple emotionality test. There is general agreement that movement along the walls and the absence of movement (freezing) immediately after being placed in the apparatus indicate emotionality. Conversely, entering the central area is considered a sign of a low level of emotivity (Corman \& Shafer, 1968; Whimbey \& Denenberg, 1967). Our results showed that rats injected with vasopressin showed less peripheral locomotor behavior during the first session, and that they entered the central squares of the open field significantly more often, than the rats injected with placebo. Thus, if the criterion mentioned above are valid, vasopressin seems to have induced a decrease in emotional reactivity.

Vasopressin also induced a state of prolonged immobility that could be characterized as "drowsiness." The fact that its frequency gradually increased is consistent with a hypothesis of habituation. Thus, if the first injection of vasopressin induced a decrease in emotionality, then the following injections seem to 


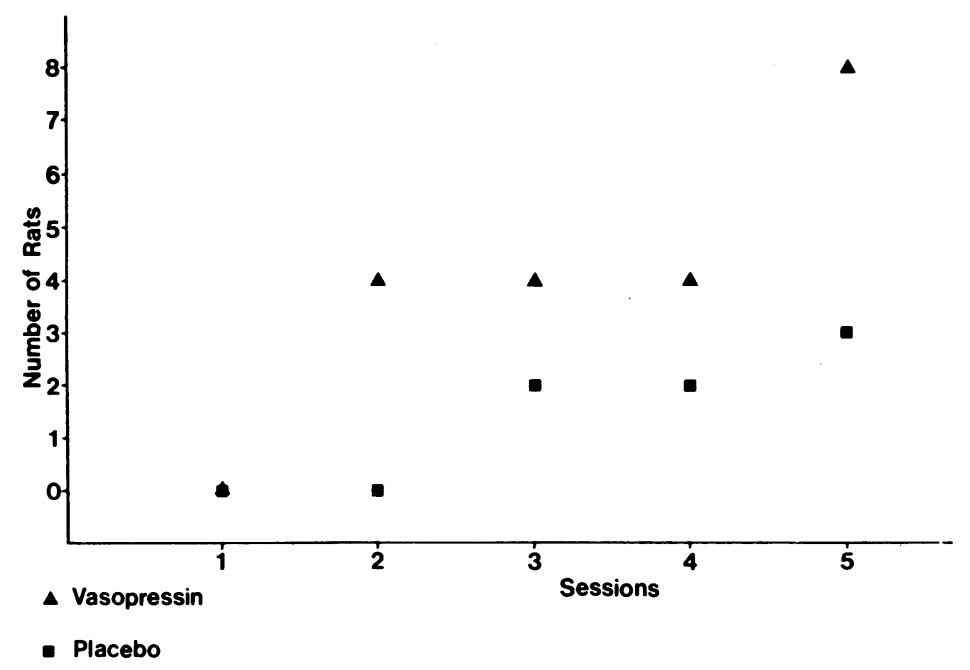

Figure 4. Evolution of the numbers of rats demonstrating locomotor immobility.

have accentuated this effect and to induce a state of habituation.

Other studies have also analyzed the effect of vasopressin on locomotor activity. In contrast with our findings, de Wied and Gispen (1977), Hostetter, Sharon, and Kozlowsky (1977), and Schultz, Kovacs, and Telegdy (1974) did not observe any change in ambulatory activity in rats injected with vasopressin, while Bohus (1971) found a decrease in the amount of behavior in the open-field situation after vasopressin. Conversely, rats with hereditary diabetes insipidus showed a higher locomotor activity both along the walls and in the central field (Bohus, van Wimersma Greidanus, \& de Wied, 1975). Finally, Krejci, Kupkova, Metys, Barth, and Jost (1979) noted a depression of locomotor activity after injections of deamino-carba-vasopressin. Lysine-vasopressin and desglycinamide-lysine-vasopressin, however, were ineffective in this respect. The contradictory results from these two groups of studies, plus the data reported here, could be the result of procedural variations. For example, the strains of rats differ; the Sprague-Dawley strain, which was used in the present experiment, is considered to be more emotional than the Wistar strain generally used by the above-mentioned investigators. Furthermore, the physical and environmental characteristics of the apparatus are important too. The differences in the shape of the apparatus (circular or square) and the level of illumination have an effect on open-field behavior. Furthermore, the testing procedure has been found to be important. Animals ambulate differently depending on whether they are placed in the center of the open field or in a corner. These parameters and their consequences are discussed in detail by Walsh and Cummins (1976). In conclusion, if one accepts open-field test as appropriate for measuring the emotivity level of rodents as well as the emotivity criteria mentioned above, and if one takes into account possible strain-specific behavior and any unknown peripheric effects of vasopressin, then our results demonstrate that vasopressin does affect emotionality in rats.

\section{REFERENCES}

AdER, R., \& DE WiED, D. Effects of lysine-vasopressin on passive avoidance learning. Psychonomic Science, 1972, 29, 46-48.

BoHus, B. Effect of hypophyseal peptides on memory functions in rats. In G. Adam (Ed.), Biology of memory. New York: Plenum Press, 1971.

Bohus, B., Ader, R., \& DE Wied, D. Effects of vasopressin on active and passive avoidance behavior. Hormones and Behavior, 1972, 3, 191-197.

Bohus, B., Gispen, W. H., \& DE WiED, D. Effects of lysinevasopressin and ACTH 4-10 on conditioned avoidance behavior of hypophysectomized rats. Neuroendocrinology, 1973, 11, 137-143.

Bohus, B., van Wimersma Greidanus, Tu. B., \& De Wied, D. Behavioral and endocrine responses of rats with hereditary hypothalamic diabetes insipidus (Brattleboro strain). Physiology \& Behavior, 1975, 14, 609-615.

Bookin, H. B., \& Pfeifer, W. Effect of lysine-vasopressin on pentylenetetrazol-induced retrograde amnesia in rats. Pharmacology, Biochemistry and Behavior, 1977, 7, 51-54.

Corman, C. D., \& Shafer, J. N. Open-field activity and exploratory behavior. Psychonomic Science, 1968, 13, 55-56.

DE WIED, D. Influence of anterior pituitary on avoidance learning and escape behavior. American Journal of Physiology, 1964, 207, 255-259.

DE WIED, D. The influence of the posterior and intermediate lobe of the pituitary and pituitary peptides on the maintenance of conditioned avoidance response in rats. International Journal of Neuropharmacology, 1965, 4, 157-167.

DE WIED, D. Long term effect of vasopressin on the maintenance of a conditioned avoidance response in rats. Nature London, 1971, 232, 58-60.

DE WIED, D., \& Bohus, B. Pituitary neuropeptides and behavior. In K. Juxe, T. Hökfelt, \& R. Luft (Eds.), Central regulation of the endocrine system. New York: Plenum Press, 1979.

de Wied, D., Bohus, B., \& van Wimersma Greidanus, Tu. B. 
Memory deficit in rats with hereditary diabetes insipidus. Brain Research, 1975, 85, 152-156.

DE Wied, D., \& Gispen, W. H. Behavioral effects of peptides. In H. Gainer (Ed.), Peptides in neurobiology. New York: Plenum Press, 1977.

Flexner, J. B., Flexner, L. B., Hoffman, P. L., \& Walter, R. Dose-response relationships in attenuation of puromycin-induced amnesia by neurohypophyseal peptides. Brain Research, 1977, 134, 139-144.

HALl, L. S. Emotional behavior in the rat: Defecation and urination as measures of individual differences in emotionality. Journal of Comparative Psychology, 1934, 18, 385-403.

Hostetter, G., Sharon, L. J., \& Kozlowski, P. G. Vasopressin affects the behavior of rats in a positively-rewarded discrimination task. Life Sciences, 1977, 21, 1323-1328.

Krejci, I., Kupkova, B., Metys, J., Barth, T., \& Jost, K. Vasopressin analogs: Sedative properties and passive avoidance behavior in rats. European Journal of Pharmacology, 1979, 56, 347-353.

Lande, S., Witter, A., \& de Wied, D. Pituitary peptides. An octapeptide that stimulates conditioned avoidance acquisition in hypophysectomized rats. Journal of Biological Chemistry, 1971, 246, 2058-2062.

Rigter, H., van Riezen, H., \& DE Wied, D. The effects of ACTH- and vasopressin analogues on $\mathrm{CO}_{2}$-induced retrograde amnesia in rats. Physiology \& Behavior, 1974, 13, 381-388.

Schultz, H., Kovacs, G. L., \& Telegdy, G. Effect of physiological doses of vasopressin and oxytocin on avoidance and exploratory behaviour in rats. Acta Physiologica Academiae Scientiarum Hungaricae, 1974, 45, 211-215.

Valtin, H., \& Schroeder, H. A. Familiar hypothalamic diabetes insipidus in rats (Brattleboro strain). American Journal of Physiology, 1964, 206, 425-430.

van Ree, J. M., Bohus, B., Versteeg, D. H. G., \& de Wied, D. Commentaries. Neurohypophyseal principles and memory processes. Biochemical Pharmacology, 1978, 27, 1793-1800.

van Wimersma Greidanus, TJ. B., Bohus, B., \& de Wied, D. The role of vasopressin in memory processes. In W. H. Gispen, Tj. B. van Wimersma Greidanus, B. Bohus, \& D. de Wied (Eds.), Hormones, homeostasis and the brain. Progress in brain research (Vol. 42). Amsterdam: Elsevier, 1975.

Walsh, A. E., \& Cummins, R. A. The open-field test: A critical review. Psychological Bulletin, 1976, 83, 482-504.

Whimbey, A. E., \& Denenberg, V. H. Two independent behavioral dimensions in open-field performance. Journal of Comparative and Physiological Psychology, 1967, 63, 500-504.

(Received for publication April 1, 1980; revision accepted October $7,1980$. .) 